\title{
Mediating Effecting of Strategic Management Accounting Application in the Relationship Between Network Collaboration and Performance in Vietnam Tourism Sector
}

\author{
Phan Thi Thuy NGA ${ }^{1^{*}}$ \\ ${ }^{1}$ Department of Accountancy, University of Finance and Accountancy, Quang Ngai Province, Viet Nam \\ *Corresponding author: phanthithuynga@tckt.edu.vn
}

\begin{abstract}
The study examines the mediating effects of strategic management accounting (SMA) on the relationship between network collaboration and financial and non-financial performance. The model is advanced and tested by using the data collected from 326 tourism businesses in the central of Vietnam by SmartPLS. The findings show that SMA has a significant indirect impact on the relationship between network collaboration and financial performance.
\end{abstract}

\section{Research purpose:}

This study examines the mediating effects of SMA on the relationship between network collaboration and financial and non-financial performance.

\section{Research motivation:}

This research will provide empirical evidences on the impact of new factors on SMA by considering contingency theory for explaining relationship and developing a new model.

Research design, approach and method:

A model is tested using partial least - squares path modeling and data were collected from a sample of 326 tourism business in the central of Vietnam.

Main findings:

The findings show that SMA has a significant indirect impact on the relationship between network collaboration and financial performance.

\section{Practical/managerial implications:}

Tourism leaders may realize their important roles in affecting outcomes through SMA application, especially in their network collaboration.

Keywords: Strategic management accounting; Strategic management accounting techniques; Network collaboration; Financial performance, Non- financial performance; Contingency theory; Tourism business.

\section{INTRODUCTION}

Simmond (1981) introduced the term "strategic management accounting" first, which includes the provision of analyzing competitor datas in developing and monitoring business strategy. But it was not until 2000, Guilding et al (2000) published their first empirical study to evaluate the SMA techniques' application (12 techniques) in New Zealand, the United States and the United Kingdom.

A surge in the number of empirical studies on strategic management accounting (SMA) since 2000s shows that SMA application is more actualized than before. The findings in the empirical studies have made changes in the role, position and value of applying of this tool
(Arunruansirilert \& Chonglertham, 2017; Cadez \& Guilding, 2008; Cinquini \& Tenucci, 2009; Guilding et al., 2000; Lisa, 2005; Kalkhouran et al., 2017; Turner et al., 2017), and it is higher appreciated in many countries in the world from the developed countries to the developing ones (Rasid et al., 2020). In Vietnam, the first reseach is Doan's (2012), reccently having reseach of Bui (2020), Le (2020) and Trinh (2018), they all do research about SMA in their thesis. These researches show that SMA application in firms has been more benefit and the popular in Vietnam recently.

A limitation of these researches is that the theoretical framework has been unclarified and confusing when applied in practice. Therefore, most of these studies only use the concept of Cadez \& Guilding (2008) 
mentioned before, which is a set of strategically oriented accounting techniques to promote their strengths and exploit competitive advantages.

SMA is considered as a management tool, so the effective application of this tool depends on the role of receiving, processing and synthesizing information from business activities to improve operational efficiency. The application of this tool depends heavily on contextual factors (Cadez \& Guliding, 2008), especially competition or unstable environment, which is the condition for SMA to be born and developed. However, the collaboration is an inevitable trend to support companies in positioning their operations and their competitive advantage in the integrated economy, which lead to better integration, survival and development of firms in line with their strategies. Hence, managers must pay attention to the collaborative network's effect on SMA's choice because it is a critical SMA design foundation. In contrary, the SMA application is the key of information helping companies, especially tourism firms in the Central region of Vietnam find out and exploit the collaboration effectively to create specific strengths in strategic tourism development and eliminate the shortcomings in business and inherent competition, such as fragmentation and separation and increase their performance.

Tourism businesses have been chosen as research objects, as this is a sector facing with the drastic changes in the business environment, just as a smoke-free industry and having a connection with many partners even competitors to survive and develop. Tourism in Vietnam has continuous improvement in the rankings of the World Economic Forum (WEF), ranked 63/140 countries. According to the Annual Report on Vietnam's tourism, 2019 is considered the 10th consecutive year of the development, attracting 18 million international visitors, 85 million domestic tourists, earning more than 755 trillion VND, contributing $9.2 \%$ of GDP. Significantly, the central of Vietnam was the highlight with beautiful and famous seas with long beaches. This region is also endowed with a natural location, has many pristine relics. Many prestigious organizations worldwide recognized some of these natural landscapes as world cultural heritages and intangible cultural heritages. While stretching along the beaches, we can easily reach many high-end resorts with various tourism products, especially cultural tourism, particularly in Hue, Da Nang, Hoi An and Khanh Hoa.

The remainder of this paper is organized as follows. Section 2 focuses on the literature review and hypothesis development. Section 3 focuses on methodology. Section 4 outlines the results, section 5 outlines conclusion and the limitation of this study.

\section{LITERATURE REVIEW AND HYPOTHESIS DEVELOPMENT}

\subsection{Literature review}

In the early 1970 s, the competition among enterprises became more intense. Businesses need to develop internal strengths and create opportunities from the external environment's challenges to gain a competitive advantage in the market. Strategic management accounting was first mentioned by Simmond (1981) when he realized that information collection and comparison with competitors are necessary to help companies compete and gain their competitive position advantage as well. This first discovery shows that the external orientation is changing with traditional management accounting's internal view. Many researchers have risen, evaluated and shaped various concepts before the 2000s, such as Simmond (1981), Bromwich (1990), Roslender \& Hart (2010). Most points of view agree that SMA is a set of techniques to provide strategic orientation information. Although SMA is considered a loose set in providing strategic information, it is accepted and developed in later empirical studies.

Many previous papers show evidence that SMA has been applied more widely in practice (Ma \& Tayles, 2009), although there are many different views on each SMA technique's quantity and content. For example, some researchers report that activity-based costing $(\mathrm{ABC})$ is only instantaneous pricing, accuracy and allocation techniques and do not support the strategy (Kaplan, 1984; Guilding et al., 2000) but in the opposite view, other authors argue that thanks to ABC's application, strategic decision-making implications are more precise and manipulative (Cinquini \& Tenucci, 2009; Cadez \& Guilding, 2008; Guilding et al., 2000; Langfield-Smith, 2008; Pavlatos, 2013). There are also differences in the customer accounting group. Cinquini \& Tecnuci (2009) merely consider this as a technique. However, many other authors split it into three different techniques: customer benefit analysis, customer profitability analysis, and customer valuation as assets, which are the same classification by Cadez \& Guilding (2008). Besides, environmental management accounting is also an SMA technique (Smith, 1997; Tanc \& Gokoglan, 2015), but no study using it as an SMA technique in empirical studies.

Reviewing previous researches, SMA includes 18 techniques divided into six groups (1) Costing; (2) Planning, control and performance measurement; (3) Strategic decision - making; (4) Competitive accounting; (5) Customer accounting and (6) The environmental management accounting (see Appendix).

SMA is assessed as the mediating effecting in many empirical studies. Cadez \& Guliding (2008) assessed the mediating effecting of SMA in the relationship between Accountants'participation in trategic decision making process and performance. The results show that there is an indirect impact through SMA, meaning that thanks to 
the application of SMA, the role of accountants in participating in the strategic decision-making process helps to improve business performance. Next, Kalkhouran et al (2017) also tested it in the relationship between CEOs' characteristics and performance, specifically, the CEOs' education and evolvement in networks when applying SMA will promote increased financial performance. In Viet Nam, Trinh (2018) test the mediating role of SMA in the relationship between intellectual capital and business performance, the results show that there is no direct correlation between intellectual capital and performance. But thanks to SMA, this relationship is positive, meaning that by applying SMA, part or all of the elements of intellectual capital will help improve business performance even more.

So, the mediating effecting of SMA is nesccesary for the relationship between network collaboration and performance. The finding will provides tourism leaders may realize their important role in effecting outcomes by SMA application, especially in their network collaboration in increasing their performance.

\subsection{Hypothesis developing}

\section{Network collaboration and SMA appication}

Based on the contingency theory (Gaibraith, 1973; Scott, 2005), it showed that SMA application was depended on the organizational context factors (Chenhall \& Smith, 1998), so context's changing will effect to the SMA application and the ability to provide information for managers. As a management tool, SMA collects and processes the information to provide strategic management implementation, because it requires information on related activities from internal and external more.

Collaboration network is a research concept in tourism business, usually associated with a destination that represents the linkage between different entities such as suppliers, distributors, competitors, public organizations, government... (Ramayah et al., 2011). In which trading partners develop a long-term cooperative effort and a common orientation towards meeting their individual and mutual goals (Ramayah et al., 2011). These partners are interdependent, more openly share information, engage in greater future planning, and tend to take a more constructive problem-solving approach to solve problems (Sriram et al. 1992).

In the globalization and the sharing economy, linking or collaborating between businesses is an important factor for managers to pay attention in both competition and position for development. For sustainable development, the factor of network collaboration in tourism - service industry will also be a factor to consider the correlation with SMA because these are relationship that creates many information problems which SMA will be a supporting tool.

The network collaboration is an exploratory factor in this study because it is based on the perspective when applying strategic management accounting, the cooperative activities between stakeholders will also become sources of information need processed to provide strategic management accounting. The cooperation network brings many benefits related to cost groups, customers, suppliers, even the tourism environment, which are also the objects that the SMA techniques refer to. Based on contingency theory, hypothesis $\mathrm{H} 1$ is proposed:

H1: The collaborative network is positively associated with SMA application.

\section{Network collaboration and performance}

Cooperation between different partners in the tourism business has created more opportunities to develop the diversity of tourism products. Many in-depth studies on cooperative network activities in tourist destinations such as Rodolfo (2012); Wang \& Fesenmaier (2007) showed to be related to increased tourism performance at that location. Ramayah et al. (2011) developed from the connection of previous studies that demonstrated that cooperation has an impact on performance, especially when there is commitment and communication which is tested in tourism in Penango in Malaysia.

On the basis of inherent activities of the tourism service industry as well as inheritance of the research of Ramahay et al (2012), the following hypotheses are proposed:

Hypothesis H2a: Network collaboration is positively correlated with financial performance.

Hypothesis H2b: Network collaboration is positively correlated with non-financial performance.

\section{SMA application and performance}

This is the factor mentioned by most of the studies, because it is an indispensable thing when businesses implement any tools and methods, just hoping to promote the performance of the business. Cadez \& Guilding (2008); Kalkhouran et al (2017) came to the same conclusion that the SMA application will promote the performance of enterprises operating in all business fields or all service areas. Moreover, the performance of enterprises is now measured not only in financial but also non-financial aspects (Doan, 2012). This relationship is proved in the recently reseaches of Bui (2020), Le (2020) and Trinh (2018) in Vietnam. Therefore, on the contingency theory, the following hypotheses are proposed:

H3a: SMA application is positively correlated with financial performance.

H3b: SMA application is positively correlated with non - financial performance. 


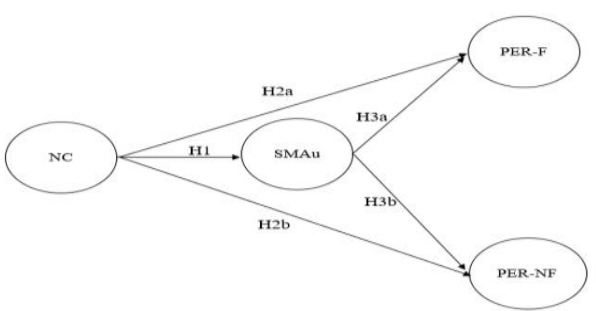

Figure 1. Proposed model

(Source: Author's proposed model)

\section{METHODOLOGY}

\subsection{Data}

Our data sample is from tourism businesses: travel, accommodation, transportation, entertainment, shopping complex in the central of Vietnam, from Hue to Khanh Hoa.

Data used for analysis are information collected directly and emailed based on a pre-designed survey questionnaires for the members of the Board of Directors, Management Board (18.1\%); accountants and chief accountants $(50.3 \%)$; and other department managers $(31.6 \%)$. Respondents with bachelor's or higher education are the majority $(>80 \%)$ with the least working experience (less than ten years) accounting for $35 \%$ and the highest working experience (over 20 years) accounting for $10.1 \%$. We conduct the data collection from November 2019 to December 2020. The results are synthesized and processed to reach a final sample including 326 units with the characteristics described in this table 1 .

Table 1. Sample characteristics

\begin{tabular}{lcc|}
\hline \multicolumn{1}{|c}{ Personality } & Number & Rate \\
Position & 59 & \\
CEOs & 103 & $31,6 \%$ \\
Other chief & 107 & $32,8 \%$ \\
Chief Accountant & 57 & $17,5 \%$ \\
Accountant & & \\
Acedemic & 54 & $16,6 \%$ \\
College & 211 & $64,7 \%$ \\
Bachelor & 58 & $17,8 \%$ \\
Master & 3 & $0,9 \%$ \\
Doctor & & \\
Experience & & \\
Less than 10 years & 114 & $35,0 \%$ \\
From 15 to less than 15 years & 122 & $37,4 \%$ \\
From 15 to less than 20 years & 57 & $17,5 \%$ \\
Over 20 years & 33 & $10,1 \%$ \\
\hline
\end{tabular}

\begin{tabular}{|lcc|}
\hline \multicolumn{1}{|c}{ Enterprise } & Number & Rate \\
Capital & & \\
Less than 20 billions dong & 73 & $22,4 \%$ \\
From 20 to less than 50 billions dong & 90 & $27,6 \%$ \\
From 50 to less than 100 billions dong & 106 & $32,5 \%$ \\
Over 100 billions dong & 57 & $17,5 \%$ \\
Number of operating years & & \\
Less than 10 years & 65 & $19,9 \%$ \\
From 10 to less than 15 years & 106 & $32,5 \%$ \\
From 15 to less than 20 years & 78 & $23,9 \%$ \\
Over 20 years & 57 & $17,5 \%$ \\
\hline
\end{tabular}

(Source: Author calculated by SmartPLS software)

\subsection{Measures}

SMA application (SMAu) is understood as recording, processing, synthesizing, evaluating, analyzing information related to what level firms apply SMA techniques. The scale of SMA application is from the research of Cadez \& Simmond (2008) and Smith et al. (1997), Tanc \& Gokoglan (2015). We measure each observed variable with the Likert scale from 1 (do not use/use very little) to 5 (use a lot). The purpose is to assess the SMA application level, not to analyze the technique's usage in depth. We describe the core content of eighteen SMA techniques to ensure correct understanding of survey subjects. (See Appendix)

Network collaboration (NC) is measured, ranging from 1 (Strongly disagree) to 5 (Strongly agree). The related questions focus on the following topics: new services development (Tsai, 2003); marketing; receiving and sharing information about market and customers (Palmer \& Bejou, 1995); investment in infrastructure, planning and construction of tourism projects (Vernon et al., 2005; Dredge, 2006); sharing tourism resources (Pfeffer \& Salancik, 1978); training human resources for tourism; and other things such as safety, insurance, sponsorship (Baggio, 2011; Lemmetynien \& Go, 2009; Rao et al., 2016).

Performance is measured as finance and non-finance, based on the degree of agreement on the increase of both financial and non-financial measures using the Likert scale, from 1 (Strongly disagree) and 5 (Strongly agree). Inheriting from the studies of Cadez \& Simmond (2008), Doan (2012) Turner et al (2017) on the basis of synthesis from the research of Kaplan \& Norton (1996); Hopue \& James (2000); Prieto \& Revilla (2006), the business performance scale is synthesized to ensure that it is suitable with the current industry and environment.

Financial performance (PER-F) is measured through: market share, revenue, profit margin, return on investment and stable cash flow. 
Non-financial performance (PER-NF) is measured through: customer satisfaction, product/service quality, human resource development and corporate reputation and brand.

In our research, we use the partial least squares regression (PLS) by SmartPLS 33.0 software to achieve our goal. According to Henseler et al. (2015), this method shows more benefits in testing multi-dimensional correlations among variables and limiting the model's defects than other methods. PLS analysis follows two below steps (Hair et al., 2016):

First, we test the measurement model, such as testing each variable's scale, construct reliability and validity, and discriminant validity of the variables in the model to ensure the reliability and appropriateness of the proposed model. We also test the multi-collinearity phenomenon in the model.

Second, we test the structural model with the Bootstrapping technique to estimate the path coefficients' magnitude and significance at $95 \%$. Then, we assessed the influence of studied factors and evaluate the significance of the research model.

\section{RESULTS AND DISCUSSION}

\subsection{Testing measurement model}

Table 2 presents the results of evaluating the reliability and convergence of each variable's scale. We can see that the load factors' values are greater than 0.5, Cronbach's Alpha is greater than 0.5, and Composite realiability is also greater than 0.7 . The results suggest that the convergence of the variables is very high, demonstrating the consistency of each variable's scale (Fornell \& Larcker, 1981).

VIF values of the variables (in Table 2), all lower than 3 , suggest eliminating the multi-collinearity defect in the research model (Hair et al., 2019).

Also, we use the Fornell - Larcker and HTMT criteria to test discriminant validity. The test parameters are within the acceptable range (according to Hair et al. (2016) and Henseler, Hubona \& Ray (2015)). This result in Table 3 proves that the variables' scales have achieved discriminant validity, meaning that the independent variables' scale is suitable to test the structural model.

\subsection{Structural model testing}

We conduct the Bootstrap technique 5000 times to test the structural model. The results are shown in Table 5 (with a 5\% significance level).
Table 2: Reliability and convergence test

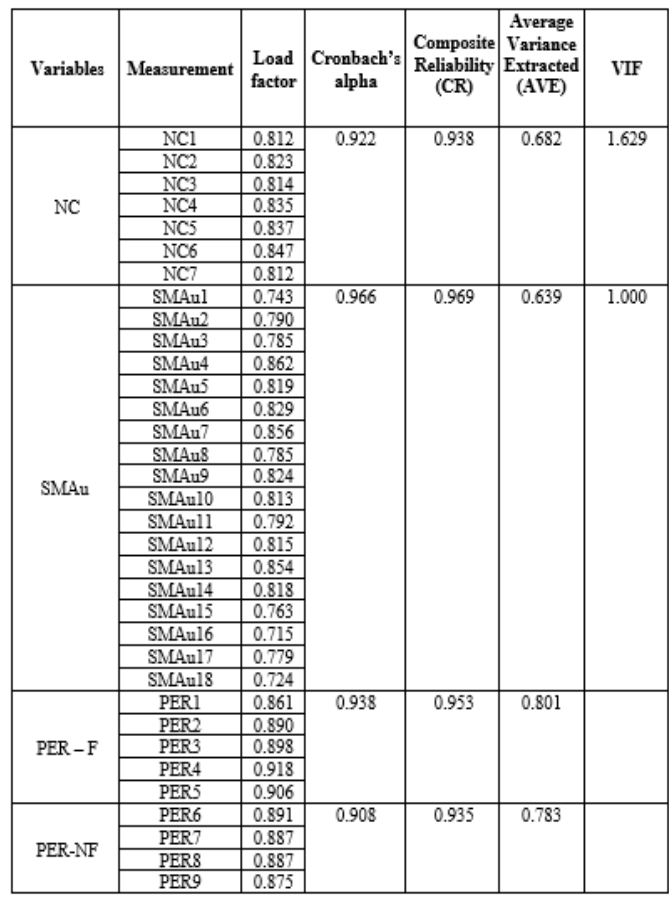

(Source: Author calculated by SmartPLS software)

Table 3: Result of discriminant validity test

Fornell-Larcker Criterion

\begin{tabular}{|l|c|r|r|r|}
\hline & \multicolumn{1}{|l|}{ NC } & \multicolumn{1}{l|}{ PER-NF } & \multicolumn{1}{l|}{ PERF } & \multicolumn{1}{l|}{ SMAu } \\
\hline NC & $\mathbf{0 . 8 2 6}$ & & & \\
\hline PER-NF & 0.506 & $\mathbf{0 . 8 8 5}$ & & \\
\hline PERF & 0.548 & 0.785 & $\mathbf{0 . 8 9 5}$ & \\
\hline SMAu & 0.621 & 0.356 & 0.448 & $\mathbf{0 . 7 9 9}$ \\
\hline
\end{tabular}

Heterotrait-Monotrait Ratio (HTMT)

\begin{tabular}{|l|l|l|l|l|}
\hline & \multicolumn{1}{l|}{ NC } & PER-NF & PERF & SMAu \\
\hline NC & & & & \\
\hline PER-NF & $\mathbf{0 . 5 4 3}$ & & & \\
\hline PERF & 0.586 & $\mathbf{0 . 8 4 6}$ & & \\
\hline SMAu & 0.653 & 0.370 & $\mathbf{0 . 4 6 6}$ & \\
\hline
\end{tabular}

(Source: Author calculated by SmartPLS software)

Table 4: Structural model test

\begin{tabular}{|l|r|r|r|r|r|}
\hline & $\begin{array}{c}\text { Original } \\
\text { Sample } \\
(\mathbf{O})\end{array}$ & $\begin{array}{c}\text { Sample } \\
\text { Mean } \\
(\mathbf{M})\end{array}$ & $\begin{array}{c}\text { Standard } \\
\text { Deviation } \\
\text { (STDEV) }\end{array}$ & $\begin{array}{r}\text { T Statistics } \\
([\mathbf{O} / \text { STDEV|) }\end{array}$ & P Values \\
\hline NC $>$ PER-NF & 0.464 & 0.464 & 0.065 & 7.159 & 0.000 \\
\hline NC $>$ PERF & 0.439 & 0.439 & 0.069 & 6.363 & 0.000 \\
\hline NC $>$ SMAu & 0.621 & 0.623 & 0.046 & 13.621 & 0.000 \\
\hline SMAu-> PER-NF & 0.068 & 0.068 & 0.058 & 1.163 & $\underline{\mathbf{0 . 2 4 6}}$ \\
\hline SMAu $>$ PERF & 0.175 & 0.173 & 0.062 & 2.812 & 0.005 \\
\hline
\end{tabular}

(Source: Author calculated by SmartPLS software) 
With p-values $<0.05$, it shows that $\mathrm{NC}$ is positive correlatied with both PER-F and PER-NF, NC is positive correlated with SMAu, but SMAu is only positive correlated with PER-F. Therefore, the mediating effecting SMAu was only tested in the relationship between NC and PER-F.

The new model is:

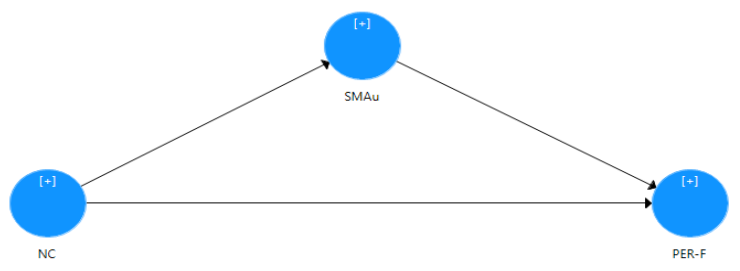

Figure 2. New model

(Source: Author drew in SmartPLS software)

\subsection{Results of testing the mediating effecting of SMAu}

Table 5. Test the mediating effecting of SMAu

\begin{tabular}{|l|r|r|r|r|r|}
\hline & $\begin{array}{c}\text { Original } \\
\text { Sample (0) }\end{array}$ & $\begin{array}{c}\text { Sample } \\
\text { Mean (M) }\end{array}$ & $\begin{array}{r}\text { Standard } \\
\text { Deviation } \\
\text { (STDEV) }\end{array}$ & $\begin{array}{c}\text { T Statistics } \\
(\mid \mathbf{O} / \text { STDEV } \mid)\end{array}$ & P Values \\
\hline NC $->$ SMAu $>$ PER-F & 0,108 & 0,108 & 0,040 & 2,726 & 0,006 \\
\hline
\end{tabular}

(Source: Author calculated by SmartPLS software)

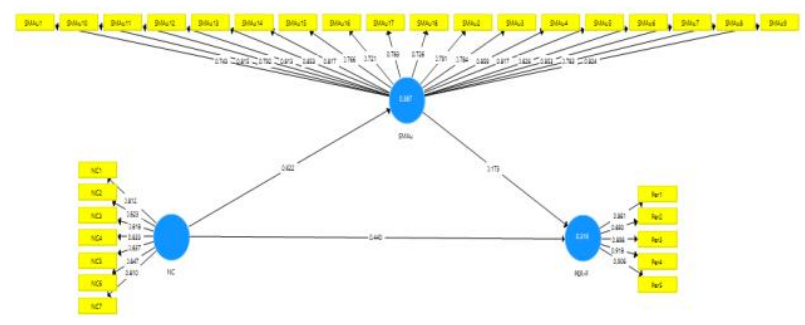

Fig. 3. Structure model estimates - PLS

(Source: Author calculated by SmartPLS software)

The results from the table 5 show that both indirect and direct effects are significant because the confidence interval contains no value 0 . The value of indirect effect of NC on PER-F is 0.108 while the level of direct effect is 0.439 , but with all p-values less than 0.05, the significance of this relationship is reached. Both direct and indirect effects are positive, it can be said that SMAu has an posivitive mediating effecting in the relationship between NC and PER-F.

The value of indirect impact of NC on PER-F is 0.108 much smaller than the value of direct impact of $\mathrm{NC}$ on PER-F. So the mediating effect of SMA on the relationship between NC and PER-F may be slight blurred. hat means in the tourism, the enties must cooperate together to achieve the performance without using management tool as SMA or not, that is the peculiarity nature of this industry. Though the result is not achieved as expected, but this partly shows the important role of SMA application in tourism sector and the mediating role of SMA in the relationship between $\mathrm{NC}$ and PER - F is existed. So the manager should care this relationship to apply SMA techniques to make strategic decision.

\section{CONCLUSION}

The results of the study were conducted at a small sample size representing a region in Vietnam, but the study's contribution can be considered useful in the context of increasing interest in the SMA application. Empirical results have emphasized the mediating role of SMA in the relationship between cooperative activities and financial performance of tourism service businesses. With the view that when applying a new management tool, administrators need to see how the function and role of this tool will support and bring value. The information that this tool brings is more comprehensive than traditional management accounting, which is the ability and strategic benefit from gathering information from outside instead of just understanding the true nature of internal information. Therefore, when a tourism business establishes a link with each different object to form a diverse cooperation network, it will more or less affect the collection and processing of information of those relationships. Therefore, it is necessary to have SMA techniques to analyze, evaluate and synthesize to make appropriate decisions because applying SMA will help the managers not only promote their trengths, exploit competitive advantages but also does not effect their nextwork collaboration to achieve the effectiveness, especially in financial peformance.

Besides the new points, the study still has some limitations. Firstly, the number of samples is collected only in the central of Vietnam, so it is not possible to generalize the factors affecting the application of strategic management accounting on a broader scale. Second, the study has not evaluated in detail each component of nextwork collaboration or strategic management accounting that has a specific impact on performance. This may be the next research direction that the authors will continue to clarify more specifically, the value of applying strategic management accounting.

\section{ACKNOWLEDGMENTS}

The authors would like to acknowledge the helpful comments provided by experts and tourism firms in the central of VietNam.

\section{REFERENCES}

[1]. Abdel-Kader, M.,\& Luther, R. (2008). The impact of firm characteristics on management accounting practices: A UK-based empirical analysis. The British Accounting Review, $40(1), 2-27$. 
[2]. Al-Mawali, H. (2015). Contingent factors of Strategic Management Accounting. Research Journal of Finance and Accounting Online, 6 (11), 2222-2847.

[3]. Arunruangsirilert, T., \& Chonglerttham, S. (2017). Effect of corporate governance characteristics on strategic management accounting in ThaiLand. Asian Review of Accounting, 22 (1), 85-105.

[4]. Augustyn, M. \& Knowles, T. (2000) Performance of tourism partnerships: a focus on York. Tourism Management, 21, 341-351.

[5]. Banker, R. D., Badhan, I. R., \& Chen, T.Y. (2008). The role of manufacturing practices in mediating the impact of activity-based costing on plant performance. Accounting, Organization, Society, 33(1), 1-19.

[6]. Baines, A. \& Langfield-Smith, K. (2003). Antecedents to management accounting change: A structural equation approach. Accounting, Organizations and Society, 28, 675-698.

[7]. Baggio, R. (2011). Collaboration and cooperation in a tourism destination: a network sciense approach. Current Issues in Tourism, 14(2), 183-189.

[8]. Bui, T. T. Q. (2020). Factors affecting the application of strategic management accounting impact on firm performance Evidence from manufacturing enterprises in South East region of Vietnam. Thesis. University of Economic Ho Chi Minh City.

Bromwich, M. (1990). The case for strategic management accounting: The role of accountitng informantion for strategy in competive markets. Accounting, Organizations and Society, 15(1), 27-46.

[10]. Cadez, S., \& Guilding, C. (2008). An exploratory investigation of an integrated contingency model of strategic management accounting. Accounting, Organizations and Soiety, 33, 836-863.

[11]. Cadez, S., \& Guilding, C. (2012). Strategy, strategic management accounting and performance: A configurational analysis. Industrial Management \& Data Systems, 112 (3), 484-501.

[12]. Chenhall, R., H. \& Langfield-Smith, K. (1998). The relationship between strategic priorities, management techniques and management accounting: An empirical investigation using a systems approach. Accounting, Organizations and Society, 23 (4), 243-264

[13]. Cinquini, L., \& Tenucci, A. (2010). Strategic management accounting and business strategy: A loose coupling?. Journal of Accounting \& Organizational Change, 6 (2), 228-259.

[14]. Corte, V.D., Aria, M. (2016). Coopetition and sustainable competitive advantage. The case of tourist destinations. Tourism Management, 54, 524 - 540

[15]. David W. Cravens. Nigel F. Piercy, (1994). Relationship Marketing and Collaborative Networks in Service Organizations. International Journal of Service Industry Management, 5 (5), 39 - 53

[16]. Dent, J. F. (1990).Strategy, organization and control: Some possibilities for accounting research. Accounting, Organizations and Society, 15(1), 3-25.

[17]. Doan, N, P. A. (2012). Factors affecting the application of strategic management accounting in Vietnamm $\mathrm{g}$ enterprises. Economic development,264, 9-15.

[18]. Dunk, A. S. (2004). Product life cycle cost analysis: The impact of customer profiling, competitive advantage, and quality of IS information. Management Accounting Research, 15(4), 401-414

[19]. Guilding, C., Cravens, K. S., \& Tayles, M. (2000). An international comparison of strategic management accounting practices. Management Accounting Research, 11, 113-135.

[20]. Henseler, J., Hubona, G., Ray, P.A. (2015). Using PLS path modeling in new technology research: update guidelines. Industrial Management \& Data Systems, 116 (1), 2-20.

[21]. Juras, A. (2014). Strategic Management Accounting - What is the current state of the concept?. Economy Transdisciplinary Cognition, 17(2), 76-83.

[22]. Fong, C., C, S. (2011). Strategic management accounting of social networking site service company in China. Journal of Technology Management in China, 6 (2). 125-139.

[23]. Kalkhouran, A. A. N., Nedaei, B. H. N.,\& Rasid, S. Z. A. (2017). The indirect effect of strategic management accounting in the relationship between CEO characteristics and their networking activities, and company performance. Journal of Accounting \& Organizational Change, 13(4), 471-491

[24]. Kaplan, R. S. (1984). The Evolution of Management Accounting. The Accounting Review, 59 (3), 390-418.

[25]. Langfield-Smith, K. (2008). Strategic management accounting: How far have we come in 25 years?. Accounting, Auditing \& 
Accountability Journal, 21 (2), 204-228.

[26]. Lem

metyinen, A., Go, F.M. (2009).The key capabilities required for managing tourism business networks. Tourism Management, 30,31-40.

[27]. Le, T. M. N. (2020). Factors affecting the application of strategic management accounting impact on firm performance Evidence from manufacturing enterprises in Vietnam. Thesis. University of Economic Ho Chi Minh City.

[28]. Libby, T., \&Waterhouse, J.H. (1996). Predicting change in management accounting system. Journal of Management Accounting Research, 8, 137-150.

[29].Lisa, J. (2005). The adoption of strategic management accounting tools in agriculture post subsidy reform: A comparative study of practices in the UK, the US, Australia and New Zealand. Chartered Institute of Management accountants, 5(7).

[30]. Lord.(1996). Strategic management accounting: The emperor's new clothes? Management Accounting Research, 7, 347-366.

[31]. Lubatkin, M.H., Simsek, Z., Ling, Y.,\& Veiga, J.F. (2006). Ambidexterity and performance in small to medium sized firms: The pivotal role of top management team behavioral integration. Journal of Management, 32 (5), 646-672.

[32]. Ma, Y., \& Tayles, M. (2009). On the emergence of strategic management accounting: An institutional perspective. Accounting and Business Research, 39(5), 473-495.

[33]. Malik, A., \& Malik, M. (2011). Strategic management accounting - A messiah for management accounting?. Australian Journal of Business and Management Research, 1(4), $1-7$.

[34]. Miles, R. E.,\& Snow, C. C. (1987). Organizational strategy, structure and Process. New York: McGraw-Hill.

[35]. Nicolaou, A. I., Masoner, M. M.,\& Welker, R. B. (1995). Intent to enhance information systems as a function of system success. Journal Information Systems, 9 (2), 93-108

[36]. Nixon, B., \& Burns, J. (2012). The paradox of strategic management accounting. Management Accounting Research, 23, 229-244.

[37]. Palmer, A. \& Bejou, D. (1995) Tourism destination marketing alliances. Annals of
Tourism Research, 22(3), 616-629.

[38]. Papadakis, V. M., \& Barwise, P. (2002). How much do CEOs and top managers matter in strategic decision-making?. British Journal of Management, 13 (1), 83-95.

[39]. Pavlatos, O., \& Kostakis, X. (2018). The impact of top management team characteristics and historical financial performance on strategic management accounting. Journal of Accounting and Organizational Change, 14 (4), 455-472.

[40]. Pfeffer, J., \& Salancik, G. R. (1978). The external control of organizations: a resource dependence perspective. New York: Harper \& Row.

[41]. Rao, U., Jach, F., Racherla, P. \& Fesenmaier, P. R. (2016). Assessing the value of collaboration in tourism networks: a case study of elkhart country. Travel Cand Tourism Research Association: Advancing Tourism Reseach Globally. [https://scholarworks.umass.edu/ttra/2007/Pre sented_Papers/67].

[42]. Rasid, M., Ali, M., \& Hossain, D.M. (2020). Strategic management accounting practices: a literature review and opportunity for future research. Asian Journal of Accounting Research, 6 (1), 109-132.

[43]. Roslender, R., \& Hart, S.(2010). Strategic Management Accounting: Lots in a Name? Www.Hw.Ac.Uk (September), 1-27.

[44]. Shank, J.K. (1989). Strategic cost management: new wine, or just new bottles? Journal of Accounting Research, 12 (4), 487-506.

[45]. Soobaroyen, T., \& Poorundersing, B. (2001). The effectiveness of management accounting systems: Evidence from functional managers in a developing country. Managerial Auditing Journal, 23 (2), 187-219.

[46]. Smith, M. (1997). Strategic Management Accounting. Issues and Cases, London: Butterworths.

[47]. Simmonds, K. (1981). Strategic management accounting. Management Accounting, 5(4), 26-29.

[48]. Tanc, A.,\& Gokoglan, K. (2015).The Impact of Environmental Accounting on Strategic Management Accounting: A Research on Manufacturing Companies. International Journal of Economics and Financial Issues, 5(2), 566-573.

[49]. Turner, M., Way, S., Hodari, D., \& Witteman, W. (2017). Hotel property performance: The role of strategic management accounting. International Journal of Hospitality Management,63, 33-43. ‘

[50]. Trinh, H. T. (2018). The mediating effecting of strategic management accounting practices 
in the realationship beween intellectual capital and corporate performance. Evidence in VietNam. Thesis. University of Economic Ho Chi Minh City.

[51]. Tsai, W. (2003). Social structure of "Coopetition" within a multiunit organization: coordination, competition, and intraorganizational knowledge sharing. Organization Science, 13(2), 179-190.

[52]. UNDSD. (2001). Environmental management accounting: Procedures and principals.United Nation Divison for Sustainable Development: Expert Working Group, New York.

[53]. Urquidi, A., \& Ripoll, V. (2013). The Choice of Management Accounting Techniques in the Hotel Sector: The Role of Contextual Factors, Journal of Management Research, 5(2), 65-82.

[54]. Vernon, J., Essex, S., Pinder, D. \& Curry, K. (2005). Collaborative policymaking - local sustainable projects. Annals of Tourism Research, 32 (2), 325-345.

[55]. Wang, Y. \& Fesenmaier, D.R. (2007). Collaborative destination marketing: A case study of Elkhart county, Indiana. Tourism Management, 28 (3), 863-875.

[56]. William, J. J. \& Seaman, A. E. (2001). Predicting change in management accounting systems: National culture and industry effect. Accounting, Organizations and Society, 26 (4-5), 443-460.

\section{Appendix}

(1) Attribute costing. This technique covers the cost of benefits provided by products served to customers. These costs are composed of grantee agreements, reinforcement, ornamentation, supply guarantee and after-sale service costs. In brief, this technique focus on product quality like product characteristics, certain sale agreements and after-sale services.

(2) Life-cycle costing. This technique is defined as calculating the total costs of a product throughout the life-cycle of the product. Such a life-cycle may cover the design, advertisement, marketing, growth, maturation, decrease, and extinction processes of a product.

(3) Quality costing. The quality of a product is a significant indicator of market competition concerning that product. Therefore, increasing and sustaining quality always provide a competitive advantage to the producer. There is a cost to both reaching and failing to reach the desired quality. Quality costs are composed of the costs to provide the desired quality and the costs to be borne by inferiority;

(4) Target costing. This technique supports cost planning in the design process of products and is put forward as a strategic profit and cost management process. It employs various ideas to reduce the costs during design, research and development phases and meets consumer demands like speed, quality and reliability. It also tries to reduce the life-cycle cost of a product. Target cost, constituting the target costing technique's base, is calculated based on the sale price to reach a target market share and expresses market-based cost. Unlike traditional "cost plus", the target cost is a function of the sale price and profit instead of costs.

(5) Value chain costing. The value herein corresponds to the monetary equivalent of the technical, economic, and social benefits and services provided to a customer in exchange for its price. Therefore, value has a monetary expression and implies the net benefit corresponding to the price paid. The value chain is composed of entire activities creating a value in all phases, from the primary raw material sources to the final goods supplied to consumers. Besides internal activities, businesses also need to develop external activities while creating value. They will thus be able to develop ties with other enterprises through external activities and, consequently, reduce costs and increase profitability. Such a case yields a significant competitive advantage for a business using value chain costing;

(6) Benchmarking. Adaptation of other businesses' good or perfect practices either in the same sector or in different sectors and efforts to improve activities by comparative assessments is defined as benchmarking. Benchmarking enterprises have the opportunity to benefit from the knowledge and experiences of others gained through trials, errors and various costs. A strategic plan covers long-term targets, and strategy leads the way to reach such targets. Understanding the strategies of other successful businesses or investigating the reasons for selecting a particular strategy are critical issues for a successful business;

(7) Integrated performance measurement. This technique covers integrated performance measurement systems pointing out the consideration of both financial and non-financial measurements. Valid measurement units are used in performance measurements.

(8) Strategic cost management. This technique uses strategy and marketing-oriented cost data to put forward and develop strategies that can provide a constant competitive advantage.

(9) Strategic pricing. Various types of information such as competitors' reactions to price fluctuations, price flexibility, economic indicators and experiences are necessary during the pricing process. Such information serves to assess competitors and their market trends together;

(10) Brand valuation. This technique includes a combination of multiple factors gained over the brand through strategic factors like planned brand gains, brand position in the market, and marketing support of the brand. It expresses the financial valuation of factors 
like leadership, permanence, internationalization, support and protection through a brand.

(11) Competitor cost assessment. Unlike the other techniques, competitor cost assessment focuses on the cost structures of competitors. Various information sources such as physical observations, standard suppliers or customers and former employees of competitors are considered information of this issue.

(12) Competitor position monitoring. This technique includes the assessment and monitoring of competitor sales, market shares, trading volumes, unit costs and trends in sales revenues to analyze the position of competitors. Within the scope of information about competitors, a business assesses its position, checks its strategy, and performs changes or revisions if needed.

(13) Competitor performance appraisal. This technique is composed of financial analyses performed by taking the information gathered from competitors' financial statements into consideration. Such analysis reveals significant information about the performance of competitors,

(14) Balanced scorecard. Kaplan and Norton first proposed the balanced scorecard in 1992 and integrated financial and non-financial dimensions into financial management. This technique aims to create a balance by establishing correlations among various multi-dimensional business strategies such as customer perspectives, internal operational processes, information, growth, and financial position.

(15) Customer profitability analysis. This technique includes the calculation of profit gained from a particular customer. Profit calculation is carried out based on monitorable sale revenues and costs for a particular customer. It is sometimes also called "customer account profitability".

(16) Lifetime customer profitability analysis. This technique expresses future projections of customer profitability to analyze customer profitability in upcoming years. The focus herein is an estimation of future revenue streams and costs for specific customer or customer groups. It explains the sustainability of future projections of customer-related accountings;

(17) Valuation of customers as assets. This technique focuses on the calculation of the value added by customers. For instance, this technique calculates the present value of future revenue streams provided by $a$ specific customer.

(18) Environmental management accounting. This technique identifies the related involves reducing impact and environmental risks and reducing environmental protection costs to increase performance. 